\title{
EXPERIMENTAL INVESTIGATIONS ON ENERGY HARVESTING FROM MECHANICAL VIBRATIONS OF BUILDINGS USING MACRO FIBER COMPOSITE
}

\begin{abstract}
The monitoring of a structure (e.g., a building) enables safe utilization of such a structure. A large number of sensors that measure selected parameters are often required in applied monitoring systems. Cables or batteries are used to power such sensors. This leads to an increase in utilization costs, as the cables have to be spatially located in a monitored building structure, or batteries have to be changed periodically. The use of the natural properties of piezoelectric materials that convert mechanical energy into electrical energy in places where sensors are mounted is a promising field of wireless monitoring system development. This article presents the results of an experimental study for an energy harvesting system using a piezoelectric composite - the Macro Fiber Composite (MFC). The device used for energy harvesting has a beam structure that was achieved by gluing steel and MFC together. In laboratory research, the characteristics of generated currents and electrical power were obtained for several values of vibration amplitude. The most important conclusion was that the resonant frequency of a piezoelectric beam generator should be established (by the selection of proper dimension or/and mass) both for the vibration frequency of the monitored mechanical structure and the vibration amplitude of this structure.
\end{abstract}

Keywords: energy harvesting, piezoelectric composite, monitoring, vibrations

\section{EKSPERYMENTALNE BADANIA NAD POZYSKIWANIEM ENERGII Z DRGAŃ MECHANICZNYCH BUDYNKÓW Z WYKORZYSTANIEM KOMPOZYTU MACRO FIBER}

Monitorowanie stanu konstrukcji np. budowlanej pozwala na jej bezpieczna eksploatację. Często $w$ stosowanych $w$ tym celu systemach monitorowania wymagane jest zastosowanie znacznej liczby czujników, mierzacych wybrane parametry. Do zasilania tych czujników stosuje się kable lub baterie, co prowadzi do większych kosztów eksploatacji konstrukcji budowlanej, gdyż $w$ przypadku kabli musza być one umieszczone $w$ monitorowanej konstrukcji, a w przypadku baterii musza być one wymieniane co pewien czas. Wykorzystanie właściwości materiałów piezoelektrycznych do konwersji energii mechanicznej na elektryczna $w$ miejscach zamontowania czujników jest obiecującym kierunkiem rozwoju bezprzewodowych systemów monitoringu. W artykule przedstawiono wyniki badań eksperymentalnych układu pozyskiwania energii, w którym wykorzystano kompozyt piezoelektryczny Macro Fiber Composite (MFC). Urządzenie do pozyskiwania energii miało konstrukcję belkowa otrzymana przez sklejenie stali $i$ MFC. W badaniach laboratoryjnych uzyskano charakterystyki generowanego natężenia prądu i mocy elektrycznej przy zmianach wartości amplitudy drgań. Na podstawie badań m.in. wykazano, że częstotliwość rezonansowa piezoelektrycznego generatora o konstrukcji belkowej powinna być ustalana (przez odpowiedni dobór wymiarów lub/i masy) zarówno na podstawie najczęściej występującej częstotliwości drgań monitorowanej konstrukcji mechanicznej, jak i na podstawie najczęściej występujących amplitud drgań tej konstrukcji.

Stowa kluczowe: pozyskiwanie energii, kompozyt piezoelektryczny, monitoring, wibracje

\section{INTRODUCTION}

The effective monitoring of some building structures demands measurements of selected parameters located in many places of the monitored structure. Such a problem exists among other things in Structural Health Monitoring (SHM) systems that are used for the behavior monitoring of several objects; e.g., bridges, aircraft, and ships (Lynch, Lohg 2006). SHM systems can be composed of dozens or hundreds of sensors, each of which must be powered. Examples of such systems are the monitoring system of three bridges in Hong Kong, which contains 300 sensors measuring several variables (Chan et al. 2006), the monitoring system of Taylor bridge in Canada, con- taining 63 sensors, measures stress in the girders (Kim et al. 2007), and the monitoring system of the span vibration of the Golden Gate Bridge in the USA, containing 64 sensors (De Roeck et al. 2000). The conventional supply of sensors in such monitoring systems requires the use of either kilometers of wire or a large number of batteries; this increases the operating costs of monitoring systems and makes the whole system not so eco-friendly when powered by batteries (Soobum et al. 2009). Hence, the development of wireless power for sensors is needed nowadays for these monitoring systems.

A promising field in wireless monitoring system development is the utilization of the natural properties of piezoelectric materials converting mechanical energy into

\footnotetext{
* AGH University of Science and Technology, Faculty of Mechanical Engineering and Robotics, Krakow, Poland; dariusz.grzybek@agh.edu.pl,micek_pt@agh.edu.pl
} 
electrical energy (the direct piezoelectric effect). The vibrations generated in many monitored structures can be a source of mechanical energy that can be converted into electrical energy in piezoelectric materials. Hence, piezoelectric materials can be used for building energy generators whose target is to supply the sensors of wireless monitoring systems. A schematic diagram of the wireless sensor node consisting of a piezoelectric generator is presented in Figure 1.

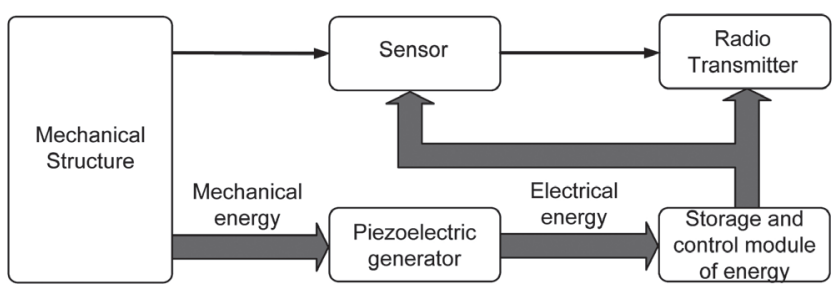

Fig. 1. Schematic diagram of wireless sensor node

The structure of the energy generator is adjusted to the type of the source of mechanical energy (Kim et al. 2011). The generators in which the main element is a prismatic beam with a rectangular cross-section are one of the structures that are used for harvesting energy from mechanical vibrations. The piezoelectric materials from four basic groups (ceramics, composites, polymers, and monocrystals) can be applied for energy conversion in such generators. The use of relatively flexible piezoelectric composites allows one to build a generator whose loads vary over time; this causes large strains on the piezoelectric elements (Yang et al. 2009). Piezoelectric composites are materials composed of piezoelectric materials of different shapes, layers of adhesive, polymer film, and the appropriately formed electrodes. The Macro Fiber Composite (MFC) is one of the piezoelectric composites that are being used in piezoelectric generators. The MFC contains a piezoceramic phase in the form of square cross-section fibers placed in the polymer matrix. The piezoelectric composite MFC is usually joined with a base material by means of gluing.

The vibrations of a building structure or its elements can be sources of mechanical energy for a piezoelectric generator. The amount of harvested electrical energy by a piezoelectric generator depends on the structure of the generator, the applied piezoelectric material in the generator, and the frequency and amplitude of the vibration from the mechanical energy source. For the cantilever beam structure of the generator, the greatest amount of harvested electrical power is generated when the resonant frequency of the generator is close to the vibration frequency of the building structure (Roundy, Wright 2004). The appropriate resonant frequency of the piezoelectric generator is achieved by the selection of the cantilever beam dimensions and by the selection of additional mass that can be mounted on the free end of the cantilever beam. Taking into consideration that the vibrations of a building structure can have various values of amplitude, the determination of relationships between the values of vibration amplitude and the amount of generated energy for the resonant frequency of the piezoelectric generator is the subject of the experimental research results presented.

\section{PIEZOELECTRIC GENERATOR STRUCTURE}

In laboratory research, the applied piezoelecric generator had the following cantilever beam structure (Fig. 2).

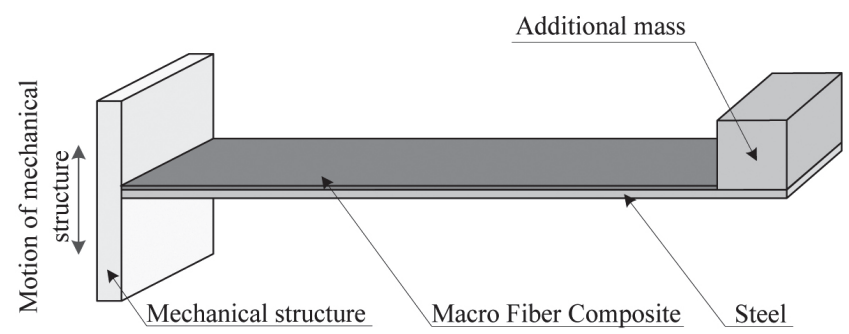

Fig. 2. Piezoelectric harvester beam structure

The mathematical model of the electrical power generated by a cantilever beam piezoelectric generator is presented in (Roundy 2005). This model was made by combining standard cantilever beam equations with constitutive piezoelectric equations and electrical circuit equations:

$$
P=\frac{V_{p}^{2}}{R_{l}}=\frac{1}{R_{l}} \frac{\left(\frac{k_{31} t p}{k_{2}}\right)^{2} \frac{1}{s \varepsilon} A_{i n}^{2}}{\left[\frac{\omega_{n p}^{2}}{\omega_{i n} R_{l} C_{p}}-\omega_{i n}\left(\frac{1}{R_{l} C_{p}}+\xi \omega_{n p}\right)\right]^{2}+\left[\omega_{n p}^{2}\left(1+k_{31}^{2}\right)+\frac{\xi \omega_{n p}}{R_{l} C_{p}}-\omega_{i n}{ }^{2}\right]^{2}}
$$


The following symbols have been used in Equation (1):

$V_{p}$ - the generated voltage,

$R_{l}$ - the load resistance,

$t_{p}$ - the thickness of the piezoelectric layers,

$k_{31}$ - the electromechanical coupling coefficient,

$k_{2}$ - the geometric constant that relates the average piezoelectric material strain to the tip deflection,

$s$ - the elastic constant of the piezoelectric material,

$\varepsilon-$ the dielectric constant of the piezoelectric material,

$A_{\text {in }}$ - the Laplace transform of the vibrations of the mechanical energy source,

$\omega_{\text {in }}$ - the vibration frequency of the clamped end of the generator beam,

$\omega_{n p}$ - the resonant frequency of the generator,

$C_{p}$ - the capacitance of the piezoelectric material,

$\xi-$ the dimensionless damping ratio.

On the basis of (1), it can be seen that the value of electrical energy generated by the cantilever beam generator depends on three groups of parameters:

- parameters connected with the applied piezoelectric material in the generator structure: $k_{31}, t_{p}, s, C_{p}$, $\varepsilon$,

- parameters connected with the structure of the cantilever beam generator: $k_{2}, \xi, \omega_{n p}$,

- parameter connected with the electrical circuit: $R_{l}$.

For the assumed structure of the piezoelectric generator, the values of the parameters mentioned above are constant in the presented laboratory research.

Taking into consideration the assumption that the vibration frequency of mechanical energy source $\omega$ is equal to the vibration frequency of the clamped end of generator beam $\omega_{i n}$, the amount of generated electrical power is also dependent on the vibration frequency of the mechanical energy source. The last variable that influences the amount of generated electrical power is vibration acceleration $a_{i n}$ of the clamped end of the generator beam. Vibration acceleration $a_{i n}$ is described by the following known equation:

$$
a_{i n}=-\omega^{2} y_{\text {in }} \sin \left(\omega_{i n} t\right)
$$

where $y_{\text {in }}$ is the vibration amplitude of the clamped end of the piezoelectric generator beam.

In the laboratory tests, the value of vibration amplitude $y_{\text {in }}$ was changed.

\section{EXPERIMENTAL SETUP}

In the experiment, an energy-harvesting device based on a cantilever beam and the P2-type Macro Fiber Composite (MFC) material was used. The thickness, length and width of the base stainless-steel beam were, correspondingly, the following: $1.24 \mathrm{~mm}, 130 \mathrm{~mm}$ and $18 \mathrm{~mm}$. The MFC patch (from the Smart Material Corporation) was glued on the top of the steel cantilever beam. The thickness length and width of the MFC were, correspondingly, the following: $0.3 \mathrm{~mm}, 85 \mathrm{~mm}$ and $14 \mathrm{~mm}$.

The experimental setup consisting of a piezoelectric generator as well as a system generating the vibrations is presented in Figure 3.

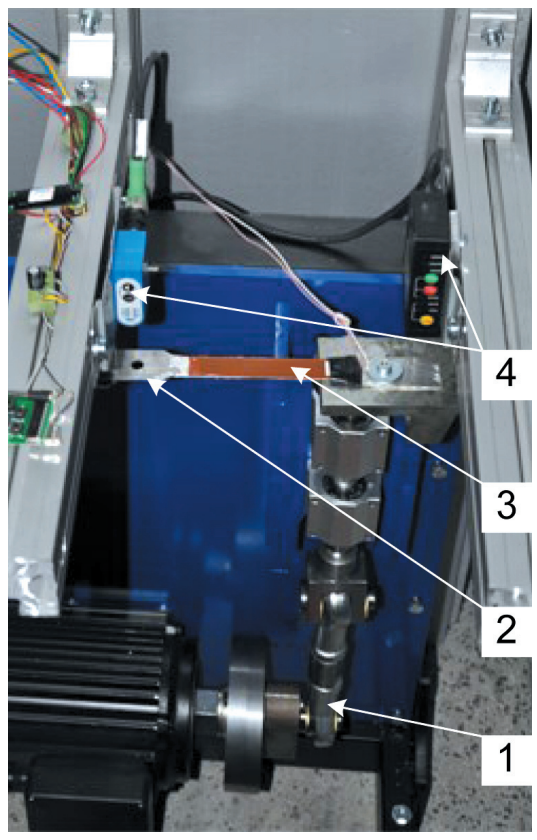

Fig. 3. Experimental setup: 1 - system of vibration generation; 2 - steel cantilever beam; 3 - piezoelectric composite (MFC); 4 - laser displacement sensors

The MFC patch was connected to a full-bridge rectifier, which in turn was connected to a capacitor and resistor (Lefeuvre et al. 2009). The resistor was treated as an electrical load. The standard full-bridge rectifier (the Graetz bridge) converted the AC voltage generated by the energy harvesting device into DC voltage. Figure 4 presents the schema of the electrical system of the energy harvesting.

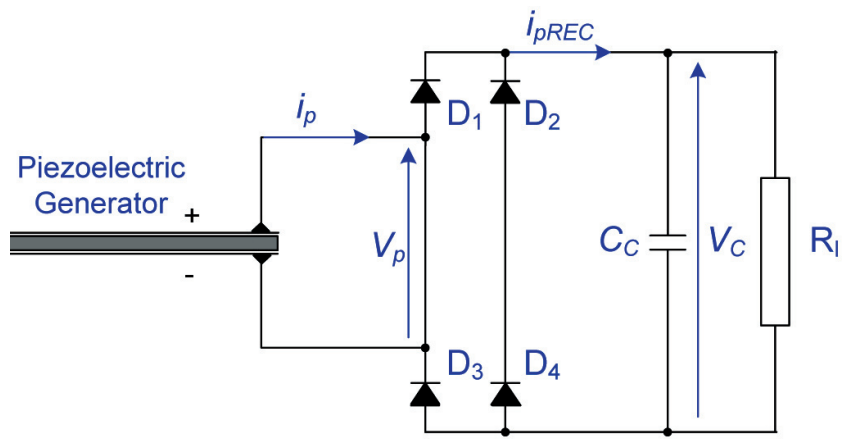

Fig. 4. Schema of electrical circuit used for energy harvesting (Lefeuvre 2009): $V_{p}$ - generated voltage by piezoelectric patch; $i_{p R E C}-$ rectified current intensity; $C_{c}$ - capacitance of capacitor; $V_{c}$ - voltage across capacitor; $R_{l}-$ load resistance 


\section{RESULTS OF LABORATORY EXPERIMENTS}

The basic assumptions from our laboratory research were as follows:

- load resistance $R_{l}$ was changeable in order to keep generated voltage $V_{p}$ by the piezoelectric generator equal to $5 \mathrm{~V}$,

- the vibration amplitude of the clamped end of generator beam $y_{\text {in }}$ was changed; its values were equal to $0.4 \mathrm{~mm}, 0.76 \mathrm{~mm}$ and $1.4 \mathrm{~mm}$,

- the applied capacitor had a constant capacity equal to $200 \mu \mathrm{F}$.

The determination of the resonant frequency of the piezoelectric beam generator (whose dimensions were presented in the previous chapter) was the first step of our experimental research. The illustrative course of the free-end displacement of the generator beam for vibration amplitude $y_{\text {in }}$ equal to $0.76 \mathrm{~mm}$ is shown in Figure 5 . The vibration frequency of the clamped end of the piezoelectric generator beam was increased from 10 to $22 \mathrm{~Hz}$ (time from 3.2 to $62 \mathrm{~s}$ ) and then decreased from 22 to $10 \mathrm{~Hz}$ (time from 62 to $124 \mathrm{~s}$ ).

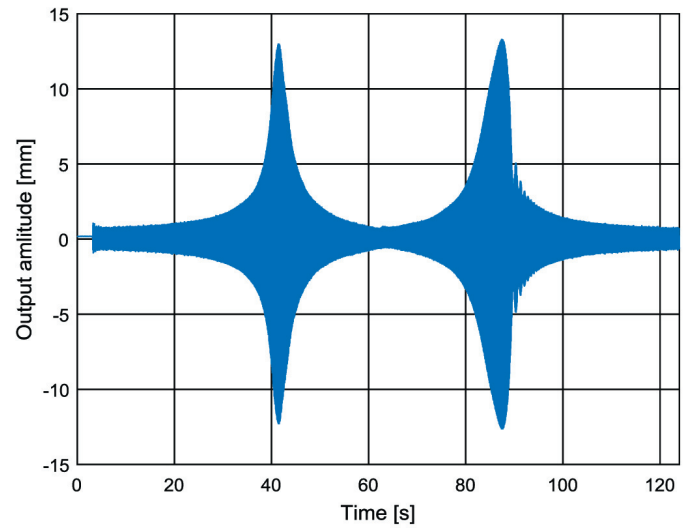

Fig. 5. Course of vibration amplitude of free end of generator beam $y_{\text {оu }}$ for vibration amplitude of clamped end of piezoelectric generator beam $y_{\text {in }}$ equal to $0.76 \mathrm{~mm}$

The experimentally determined resonant frequency of piezoelectric generator $\omega_{n p}$ for the selected values of the amplitude of vibration of the clamped end of the generator beam is presented in Figure 6.

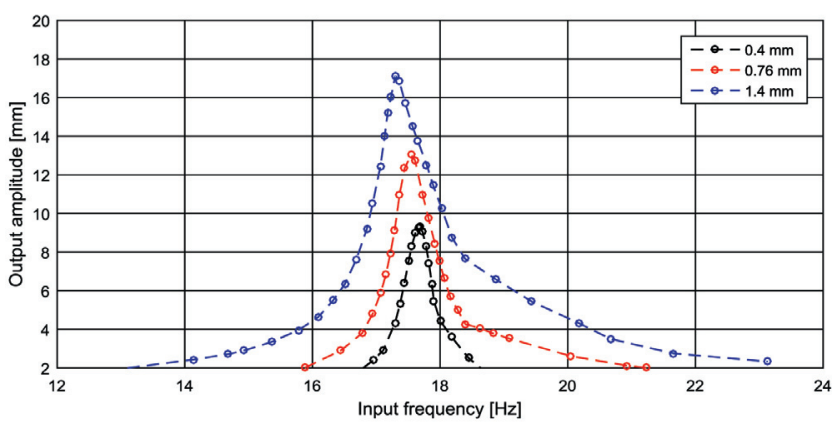

Fig. 6. Plot of vibration amplitude of free end of generator beam $y_{\text {ou }}$ for different values of vibration amplitude $y_{i n}$
On the basis of Figure 5, the resonant frequencies of the generator were determined: $17.67,17.54$ and $17.29 \mathrm{~Hz}$. These frequencies appeared for the following vibration amplitudes of the clamped end of the piezoelectric generator beam: $0.4,0.76$ and $1.4 \mathrm{~mm}$. The increase in the maximal value of the vibration amplitude of clamped end $y_{i n}$ causes the nonlinear increase of the maximal value of vibration amplitude $y_{\text {ou }}$. This increase also causes the expansion of the vibration frequency range in which the generator produced the sufficient amount of electrical power to the supply of the wireless sensor. In our laboratory experiments, such an amount of generated electrical power was obtained for vibration amplitude $y_{\text {ou }}$ (which was greater than $2 \mathrm{~mm}$ ). Hence, in Figure 6, the vertical axis starts from $2 \mathrm{~mm}$. The values of the generated current, power and range of frequency for the three selected values of vibration amplitude $y_{\text {in }}$ are presented in Table 1 .

\section{Table 1}

Results of experiments

\begin{tabular}{|l|c|c|c|c|c|}
\hline \multicolumn{1}{|c|}{ Variable } & Symbol & Unit & Test 1 & Test 2 & Test 3 \\
\hline Vibration amplitude & $y_{i n}$ & $\mathrm{~mm}$ & 0.40 & 0.76 & 1.40 \\
\hline Resonant frequency & $\omega_{n p}$ & $\mathrm{~Hz}$ & 17.67 & 17.54 & 17.29 \\
\hline Vibration amplitude & $y_{o u}$ & $\mathrm{~mm}$ & 9.29 & 13.03 & 17.13 \\
\hline Range of frequency & - & $\mathrm{Hz}$ & 1.87 & 5.35 & 10.05 \\
\hline Generated voltage & $V_{p}$ & $\mathrm{~V}$ & 5.00 & 5.00 & 5.00 \\
\hline Generated current & $i_{p}$ & $\mathrm{~mA}$ & 0.11 & 0.21 & 0.28 \\
\hline Generated power & $P_{p}$ & $\mathrm{~mW}$ & 0.55 & 1.05 & 1.40 \\
\hline
\end{tabular}

The experimentally determined dependence between vibration amplitude $y_{\text {in }}$ and maximal generated current $i_{p}$ for the maximal values of vibration amplitude $y_{o u}$ is presented in Figure 7.

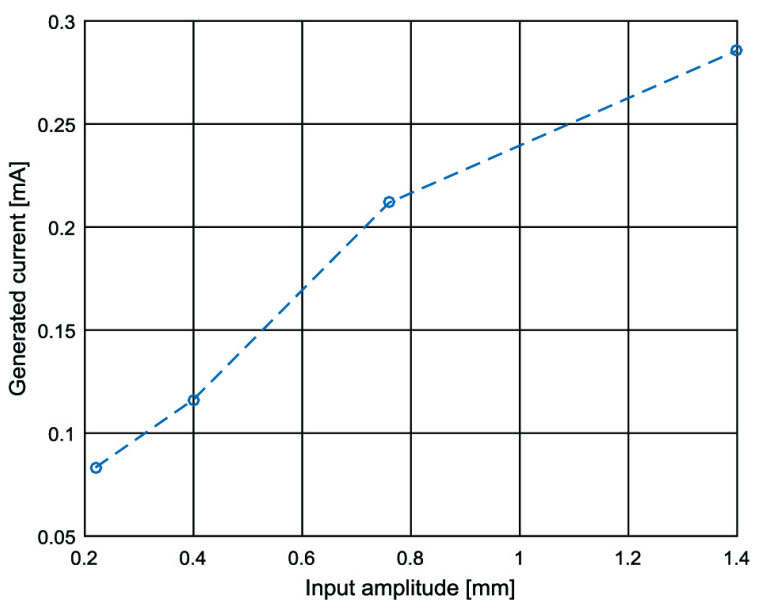

Fig. 7. Dependence between vibration amplitude $y_{\text {in }}$ and generated current $i_{p}$ 
The increase in amplitude of the vibration of clamped beam end $y_{\text {in }}$ causes a nonlinear increase in maximal generated current $i_{p}$. Taking into consideration that the generated voltage was constant (equal to $5 \mathrm{~V}$ ), it can be noticed that the increase of vibration amplitude $y_{\text {in }}$ causes a nonlinear increase in the maximal generated electrical power.

\section{CONCLUSIONS}

On the basis of the experimental research (whose selected results were shown in the previous chapters), the following conclusions have been drawn:

- the increase of amplitude of the vibration of clamped beam end $y_{\text {in }}$ causes a nonlinear increase in the maximal generated electrical power,

- the change of amplitude of the vibration of the clamped beam causes a change in the resonant frequency of the piezoelectric beam generator. The maximum-generated electrical power is obtained for this new resonant frequency,

- taking into consideration that the structure of the piezoelectric beam generator cannot be modified during its work, the resonant frequency of such a generator has to be established (by selecting the proper dimensions or/and mass) both for the vibration frequency of the building and the vibration amplitude of the building,

- the increase in the maximal value of the vibration amplitude of the clamped end of piezoelectric generator beam $y_{\text {in }}$ causes an expansion of the vibration frequency range in which the effective energy harvesting can be carried out.

\section{Acknowledgement}

The study was completed under AGH-UST's research program No 11.11.130.958 sponsored through statutory research funds, AGH University of Science and Technology, Faculty of Mechanical Engineering and Robotics, Department of Process Control.

\section{References}

Chan T.H., Yu L., Tam H.Y., Ni Y. Q., Liu S.Y., Chung W.H., Cheng L.K., 2006, Fiber Bragg grating sensors for structural health monitoring of Tsing Ma bridge: Background and experimental observation. Engineering Structures, 28, 5, 648-659.

De Roeck G., Peeters B., Maeck J., 2000, Dynamic monitoring of civil engineering structures. Proceedings of IASS-IACM, Athens, Greece.

Kim H.S., Kim J.H., Kim J., 2011, A review of piezoelectric energy harvesting based on vibration. International Journal of Precision Engineering and Manufacturing, 12, 6, 1129-1141.

Kim S., Pakzad S., Culler D., Demmel J., Fenves G., Glaser S., Turon M., 2007, Health monitoring of civil infrastructures using wireless sensor networks. Proceedings of 6th International Symposium on Information Processing in Sensor Networks, general chair: Tarek Abdelzaher, Cambridge, USA, 25-27 April, 254-263.

Lefeuvre E., Sebald G., Guyomar D., Lallart M., Richard C., 2009, Materials, structures and power interfaces for efficient piezoelectric energy harvesting. Journal of Electroceramics, 22, 171-179.

Lynch J.P., Lohg K.J., 2006, A summary review of wireless sensors and sensor networks for structural health monitoring. The Shock and Vibration Digest, 38, 2, 91-128.

Roundy S., 2005, Improving power output for vibration-based energy scavengers. Pervasive Computing, IEEE, 4, 28-36.

Roundy S., Wright P.K., 2004, A piezoelectric vibration-based generator for wireless electronics. Smart Materials and Structures, 13, 1131-1142.

Soobum L., Byeng D.Y., Byung C.J., 2009, Robust segment-type energy harvester and its application to a wireless sensor. Smart Materials and Structures, 18, 9, article no. 095021.

Yang Y., Tang L., Li H., 2009, Vibration energy harvesting using macrofiber composites. Smart Materials and Structures, 18, 11, article no. 115025 . 